\title{
Influence of dietary bulk agents (silica, cellulose and a natural zeolite) on protein digestibility, growth, feed intake and feed transit time in European seabass (Dicentrarchus labrax) juveniles
}

\author{
Jorge Dias ${ }^{(1 *)}$, Christine Huelvan ${ }^{(1)}$, Maria T. Dinis ${ }^{(2)}$, Robert Métailler ${ }^{(1)}$ \\ (1) Fish Nutrition Laboratory, Unité mixte Inra-Ifremer, Ifremer, Centre de Brest, 29280 Plouzané, France. \\ (2) UCTRA, Universidade do Algarve, Campus de Gambelas, 8000 Faro, Portugal.
}

Received December 9, 1997; accepted June 23, 1998.

\begin{abstract}
The incorporation of various bulk agents by substitution of an equivalent amount of the basal mixture was studied in terms of protein digestibility, growth performance and body composition in European seabass (Dicentrarchus labrax) juveniles. During the growth trial, triplicate groups of 40 seabass (mean initial weight: $7.0 \mathrm{~g}$ ) were grown in seawater (salinity: 35 ; temperature: $18^{\circ} \mathrm{C}$ ) over 60 days. Fish were hand-fed, three times a day, one of seven experimental diets. Bulk agents tested at 10 or $20 \%$ level of incorporation were silica, cellulose and a natural zeolite (chabamin). Feeding rates were adjusted in proportion to the percent dilution of the control diet without bulk incorporation. The incorporation of the bulk agents, at a 10 and $20 \%$ level, did not affect protein digestibility or growth performance. Dietary bulk incorporation reduced feed efficiency values, particularly at the $20 \%$ incorporation level. However, this reduction was mostly caused by the dietary nutrient dilution of the bulk-incorporated diets, rather than by a negative effect of the bulk agents as dietary ingredients. In comparison to the control treatment, bulk incorporation at 10 and $20 \%$ level did not affect protein retention values. When compared with the control diet, $20 \%$ bulk agent incorporation changed the evacuation profile of faeces and increased faecal egestion time. (C) Ifremer/Elsevier, Paris
\end{abstract}

Fish nutrition / inert fillers / digestibility / Dicentrarchus labrax

Résumé - Influence des agents liants alimentaires (silice, cellulose et une zéolithe naturelle) sur la digestibilité des protéines, la croissance, l'ingestion alimentaire et le transit digestif chez le juvénile du bar (Dicentrarchus labrax). L'effet de l'incorporation de divers agents liants alimentaires sur la digestibilité protéique, les performances de croissance et la composition corporelle sont étudiés chez le juvénile du bar (Dicentrarchus labrax). La croissance pondérale est suivie pendant 60 jours, durant lesquels des lots de 40 poissons (poids moyen initial : 7,0 g) sont élevés en eau de mer (salinité : 35 ; température : $18^{\circ} \mathrm{C}$ ). Les poissons sont nourris à la main, trois fois par jour. Des agents liants sont testés selon deux taux différents d'incorporation dans l'aliment (10 et $20 \%$ ) : la silice, la cellulose et une zéolithe naturelle (chabamin). Les taux de rationnement ont été ajustés en proportion au pourcentage de dilution du régime témoin, sans incorporation de liants. L'incorporation à 10 et $20 \%$ des divers liants n'a pas affecté la digestibilité des protéines ou les performances de croissance. L'utilisation des agents liants a entraîné une diminution de l'efficacité alimentaire, notamment avec les régimes comprenant $20 \%$ de liants. Cependant, cette réduction est surtout due à la dilution des nutriments des aliments avec les liants et non à un effet négatif des liants proprement dits. La composition corporelle des poissons entiers, à la fin de la période expérimentale, n'est pas significativement affectée par les différents régimes alimentaires. Par rapport au régime témoin, l'incorporation à $20 \%$ des divers agents liants a changé le profil d'évacuation des fèces et a augmenté le temps de transit digestif. (O Ifremer/Elsevier, Paris

Nutrition des poissons / agents liants / digestibilité / Dicentrarchus labrax

\section{INTRODUCTION}

Dietary fibre generally refers to all plant components that are not digested by the endogenous secretions of the gastrointestinal tract [15]. Recent human nutrition studies show that due to their physico-chemi- cal properties (water-holding capacity, viscosity, cation exchange capacity, molecular adsorption potential), some dietary fibres tend to reduce cholesterolemia, improve glucose tolerance and lower colon cancer incidence $[15,18,25]$. Most studies concerning the use of dietary fibres (cellulose, agar, guar gum, car-

* Corresponding author, e-mail: dias@st-pee.inra.fr 
boxymethylcellulose, alginate, carrageenan) by fish reported a growth depression and a reduction of feed intake when the fibre incorporation level exceeded $10 \%[10,14,24,32]$. Moreover, the incorporation of alginate and guar gum in rainbow trout diets lowered the digestibility of protein and lipid [36]. However, there are some studies with seabass [1] and rainbow trout $\lceil 5\rceil$ in which high dietary levels of cellulose (15$30 \%$ ) did not affect growth performance. These contradictory results suggest that there may be species differences in terms of digestion and gastric emptying rates, which affect feed intake and the utilization of nutrients [23], thus conditioning the overall growth performance.

Being indigestible, thus nutritionally unavailable, dietary fibres have been mainly used as non-nutritive fillers or dietary binders in fish feeds. In animal nutrition, besides fibres, other inert substances such as silicates (bentonites, zeolites, kaolin, diatomides, cement kiln dust) have also been used as non-nutritive fillers $[11,13,19,26,27]$. However, the dietary use of bulk agents (nutritionally unavailable substances) presents a major drawback in terms of environmental protection as they increase significantly total faecal losses.

In aquaculture, the main losses of a dietary nature are suspended solids originating both from uneaten and undigested feed and catabolic end products released as soluble wastes. The nutritional strategies for the reduction of such wastes include proper feeding practices and improved digestibility of feed [7, 17]. In recent years, the use of nutrient and energy-rich diets in which ingredients with high fibre content or indigestible carbohydrates are reduced or eliminated, has been promoted as it improves feed efficiency and reduces aquaculture effluent discharges [8]. However, even if paradoxical to the idea of reducing faecal wastes, the dietary use of some bulk agents may increase faeces cohesion, thus enhancing the efficiency of the suspended solids removal systems. Moreover, due to their high cation exchange capacity for $\mathrm{NH}_{4}^{+}$, dietary zeolites may play an important role in reducing effluent ammonia levels.

The dietary use, at 10 and $20 \%$ level of supplementation, of various bulk agents was studied in terms of protein digestibility, growth performance and body composition in European seabass (Dicentrarchus labrax) juveniles. Complementary studies on voluntary feed intake and feed egestion time were also performed.

\section{MATERIAL AND METHODS}

\subsection{Experimental diets}

A control diet was formulated to contain $56 \%$ crude protein and $13 \%$ fat. By substitution of an equivalent amount of the control mixture, six other diets were produced, in which silica (S), cellulose (C) and a natural zeolite $(\mathrm{Z})$ were incorporated as bulk agents at 10 and $20 \%$ level (table I). All ingredients were finely ground $(<800 \mu \mathrm{m})$, mixed and pelletized wet (screen diameter: $4.5 \mathrm{~mm}$ ) using a Hobart meat grinder. Pellets were then dried in a forced air dryer at $80^{\circ} \mathrm{C}$ for 10 min so that the moisture content was reduced to less than $10 \%$. The pellets were sieved to obtain particles with graded diameters (2-3 and 3-4 mm) which were used according to fish size. In diets used to measure protein digestibility and feed egestion time, $2 \%$ chro-

Table I. Ingredients and composition of the experimental diets.

\begin{tabular}{|c|c|c|c|c|c|c|c|}
\hline Ingredients of Control m & & & & & & & \\
\hline Fish meal & 72.6 & & & & & & \\
\hline Cooked potato starch & 15.0 & & & & & & \\
\hline Cod liver oil & 4.6 & & & & & & \\
\hline Soy lecithin & 1.0 & & & & & & \\
\hline Sodium alginate & 4.0 & & & & & & \\
\hline Choline $50 \%$ & 0.6 & & & & & & \\
\hline Vitamin mix & 1.0 & & & & & & \\
\hline Vitamin C & 0.2 & & & & & & \\
\hline Mineral mix & 1.0 & & & & & & \\
\hline Experimental Diets & Control & $Z 10$ & $\mathrm{Z} 20$ & S10 & $\mathbf{S} 20$ & $\mathrm{ClO}$ & $\mathrm{C} 20$ \\
\hline Control mixture & 100.0 & 90.0 & 80.0 & 90.0 & 80.0 & 90.0 & 80.0 \\
\hline Zeolite $^{2}$ & - & 10.0 & 20.0 & - & - & - & - \\
\hline Silica $^{3}$ & - & - & - & 10.0 & 20.0 & - & - \\
\hline Cellulose $^{4}$ & - & - & - & - & - & 10.0 & 20.0 \\
\hline Proximate analyses $(\%$ & & & & & & & \\
\hline Crude protein & 55.6 & 50.2 & 43.7 & 49.8 & 43.5 & 50.5 & 43.8 \\
\hline Fat & 13.5 & 11.8 & 10.5 & 11.7 & 10.6 & 11.7 & 10.6 \\
\hline Ash & 13.3 & 21.3 & 28.4 & 21.7 & 29.3 & 11.8 & 10.6 \\
\hline
\end{tabular}

${ }^{1}$ Formulation according to NRC (1981).

${ }^{2}$ Chabamin J180, Minerais de la Méditerranée, Balaruc-les-Bains, France.

${ }^{3}$ Roquette Frères, Lestrem, France.

${ }^{4}$ Touzart et Matignon, Vitry-sur-Seine, France. 
mic oxide was incorporated by substitution of an equivalent quantity of fish meal.

\subsection{Protein digestibility measurements}

Homogeneous groups of 25 seabass (mean body weight: $50 \mathrm{~g}$ ) were used to determine in triplicate the apparent digestibility coefficients (ADC) of the dietary protein by the indirect method, using $2 \%$ chromic oxide as an inert tracer. Fish were stocked in circular tanks with a conical bottom (volume: $60 \mathrm{~L}$; water-flow rate: $4 \mathrm{~L} \cdot \mathrm{min}^{-1}$ ) supplied with seawater (temperature: $18 \pm 1{ }^{\circ} \mathrm{C}$; salinity: 35 ; dissolved oxygen above $\left.7 \mathrm{mg} \cdot \mathrm{L}^{-1}\right)$. Following a 2-week period of adaptation to rearing conditions and experimental diets, faeces were collected over 10 days by the continuous filtration system developed by Choubert et al. [9]. After daily collection, faeces were frozen at $-20^{\circ} \mathrm{C}$. Pooled faeces from each group of fish were freeze-dried prior to analysis. ADC of the dietary protein was calculated using the formula reported by Maynard and Loosli [20].

\subsection{Growth trial}

Twenty-one homogeneous groups (3 replicates $x$ 7 diets) of 40 seabass (mean initial weight: $7.1 \pm 0.2 \mathrm{~g}$ ) were stocked in square tanks $(50 \times 50 \times 25 \mathrm{~cm}$; volume: $50 \mathrm{~L}$ ) supplied with a continuous flow of gravel-filtered seawater (water-flow rate: $2 \mathrm{~L} \cdot \mathrm{min}^{-1}$, salinity: 35 ; temperature: $18 \pm 1{ }^{\circ} \mathrm{C}$ ). A $12 / 12 \mathrm{~h}$ fluorescent light/dark cycle was used. For over 60 days, fish were hand-fed three times a day (09:00, 14:00, 18:00 h) one of the experimental diets. Feed intake was recorded throughout the experimental period. The feeding rate adopted for fish fed the control diet was $2 \%$ of body weight, which is a level below satiation. To provide all fish groups with an equivalent nutrient intake and assuming that bulk agents were nutritionally unavailable, the feeding rates of fish fed the bulkincorporated diets were adjusted in proportion to the percent dilution of the control diet. To follow growth and feed utilization, fish were counted and group weighed every two weeks. At the beginning of the experiment, 15 fish from the initial stock were sampled for whole-body composition analysis. At the end of the trial, 5 fish per group were sampled for the same purpose. Additionally, the liver and viscera from 5 fish per group were excized and weighed for the determination of hepatosomatic and viscerosomatic index.

\subsection{Feed consumption trials}

Two experiments were conducted to evaluate the effect of bulk agents' incorporation on voluntary feed intake. In the first trial, voluntary feed intake was analysed in relation to the different nutrient density of the diets. After an adaptation period, triplicate groups of 44 juvenile seabass (mean body weight: $26 \mathrm{~g}$ ) were fed with one of the following diets: control, Z20, S20 or C20. Fish were grown in cylindro-conical tanks (volume: $60 \mathrm{~L}$; water-flow rate: $4 \mathrm{~L} \cdot \mathrm{min}^{-1}$ ). Water tem- perature was maintained at $18 \pm 1{ }^{\circ} \mathrm{C}$. During two weeks, fish were fed a fixed ration, largely in excess, that was distributed by hand once a day $(09: 00 \mathrm{~h})$. During and after feeding, unconsumed feed was collected for $30 \mathrm{~min}$ by the continuous filtration system [9]. Daily voluntary feed intake was quantified on a dry matter basis. Fish were group weighed at the beginning and at the end of the trial.

As a complementary study on feed consumption aspects, a preliminary trial was done to test the palatability of the various diets. The experimental diets tested in this trial were control, Z10, S10 and C10. In order to reduce the effect of the different nutrient densities of the diets on feed intake, every two days the diet offered to each fish group was randomly changed. All other rearing conditions and experimental procedures to determine daily voluntary feed intake were similar to those referred to in the previous trial.

\subsection{Feed transit time trial}

In this study, feed egestion time was measured by the time course of elimination of single specific meal. It is difficult to determine the precise moment from which all the faeces from one particular meal are expelled without affecting the fish's feeding habits, as faeces egestion period generally lasts more than $24 \mathrm{~h}$. Thus, the faeces originated by a specific meal were identified by alternatively feeding fish an identical diet with or without chromic oxide incorporation as an inert tracer. Green coloured faeces were then easily identifiable. Fish, experimental diets and rearing conditions used in this study were identical to those presented in the first feed consumption trial. Fish were fed one single meal of the diets with chromic oxide, feed intake was quantified as described above and approximately $30 \mathrm{~min}$ after feeding, collection of faeces by the Choubert et al. system [9] was initiated. Hourly, the green faeces collected from each tank were weighed and their dry matter content determined. The previous day and the day after faeces collection, fish were fed the same diets but without chromic oxide incorporation.

\subsection{Analytical methods}

Chemical composition analysis of the diets, faeces and whole fish was made using the following procedures: dry matter by drying at $105^{\circ} \mathrm{C}$ for $24 \mathrm{~h}$; ash by combustion at $550^{\circ} \mathrm{C}$ for $12 \mathrm{~h}$; crude protein (microKjeldhal; $\mathrm{N} \times 6.25$ ) and fat by dichloromethane extraction (Soxhlet). Chromic oxide was determined according to Bolin et al. [2], after perchloric acid digestion.

\subsection{Statistical analysis}

Data are presented as means \pm standard deviation. To test differences between dietary treatments, all data were subjected to one-way analysis of variance and when considered appropriate, means were compared with the Student-Newman-Keuls multiple range test 
[38]. Statistical significance was tested at a 0.05 probability level. All statistical tests were performed using the SAS statistical package [28].

\section{RESULTS}

\subsection{Protein digestibility}

Data on the apparent digestibility coefficients (ADC) of protein in the experimental diets are reported in table II. The dietary incorporation of the various bulk agents, at 10 and $20 \%$ level, did not significantly affect protein digestibility.

Table II. Apparent digestibility coefficients (ADC) of dietary protein.

\begin{tabular}{lc}
\hline Diets & Protein ADC (\%) \\
\hline Control & $91.2 \pm 0.8$ \\
Z10 & $91.6 \pm 0.1$ \\
Z20 & $91.9 \pm 0.3$ \\
S10 & $91.0 \pm 0.4$ \\
S20 & $89.7 \pm 0.3$ \\
C10 & $90.1 \pm 0.2$ \\
C20 & $90.6 \pm 0.4$ \\
\hline
\end{tabular}

\subsection{Growth performance and whole-body composition}

Data on growth performance, feed and protein utilization and whole-body composition of seabass fed the different experimental diets are reported in table III. Specific growth rate (SGR) values ranged from 1.14 to 1.23 and neither daily weight gain nor growth rates were affected by bulk incorporation. The best feed:gain ratio (FGR) value was observed for seabass fed the control diet (1.26). The use of dietary bulk agents negatively affected FGR, particularly at the highest level of incorporation where FGR values ranged from 1.42 to 1.63 . However, if the percent nutrient dilution of the bulk-incorporated diets is taken into account, corrected FGR values did not differ significantly $(P<0.05)$ among experimental treatments, with values varying between 1.23 and 1.39 . In comparison to fish fed the control diet, bulk incorporation at 10 and $20 \%$ levels did not affect protein retention (as $\%$ of intake), which ranged between 25.7 and $28.6 \%$. In terms of whole-body composition, crude protein and ash content did not vary significantly between experimental treatments nor between fish at the beginning and end of the experiment. At the end of the growth trial, seabass from all experimental treatments had a lower water content and a higher fat content at the whole-body level. The hepatosomatic index (HSI) varied from 2.1 to $1.6 \%$ and bulk incorporation tended to reduce HSI values. Visceral fat represented between 3.8 to $4.5 \%$ of body weight. Some statistical differences were found in terms of HSI and viscerosomatic index (VSI), although they were not clearly attributable to any dietary changes.

\subsection{Voluntary feed intake}

The results of the first feed consumption trial relating the voluntary feed intake (VFI) of fish with the nutrient density of the diets are shown in figure 1 . The VFI of tish fed the control diet (1.31\% of initial body weight per day) was significantly lower than the values obtained for the $20 \%$ bulk incorporated diets $(1.45$, 1.47 and $1.51 \%$ for diets $\mathrm{S} 20, \mathrm{Z} 20$ and $\mathrm{C} 20$ respectively). However, if the percent nutrient dilution is taken into account, corrected VFI values do not differ between experimental treatments.

Table III. Effects of dietary bulk agents incorporation on growth performance, feed utilization efficiency and whole-body composition in juvenile seabass grown over 60 days at $18^{\circ} \mathrm{C}$ (initial mean body weight: $7.1 \pm 0.2 \mathrm{~g}$ ).

\begin{tabular}{|c|c|c|c|c|c|c|c|c|c|}
\hline & & Control & $\mathrm{Z} 10$ & $\mathrm{Z} 20$ & \$10 & 520 & $\mathrm{C} 10$ & $\mathrm{C} 20$ & Pooled SE \\
\hline Final mean body weight (g) & & 15.8 & 15.9 & 14.8 & 15.3 & 14.3 & 15.4 & 15.2 & 0.12 \\
\hline Daily weight gain (\% IBW) & & 1.94 & 1.96 & 1.91 & 1.92 & 1.74 & 1.90 & 1.95 & 0.017 \\
\hline Specific growth rate (SGR)' & & 1.23 & 1.23 & 1.22 & 1.21 & 1.14 & 1.21 & 1.23 & 0.015 \\
\hline Feed:Gain ratio $(\mathrm{FGR})^{2}$ & & $1.26^{\mathrm{a}}$ & $1.42^{b}$ & $1.54^{\circ}$ & $1.54^{\mathrm{c}}$ & $1.63^{\mathrm{d}}$ & $1.43^{\mathrm{b}}$ & $1.54^{\mathrm{c}}$ & 0.010 \\
\hline Corrected FGR ${ }^{3}$ & & 1.26 & 1.27 & 1.23 & 1.39 & 1.31 & 1.29 & 1.23 & \\
\hline Protein retention (as \% of intake) ${ }^{4}$ & & $28.2^{b}$ & $28.5^{b}$ & $28.6^{\mathrm{b}}$ & $25.7^{\mathrm{a}}$ & $26.8^{a b}$ & $27.9^{\mathrm{a}}$ & $28.5^{b}$ & 0.15 \\
\hline Hepatosomatic index (HSI) ${ }^{5}$ & & $2.10^{\mathrm{a}}$ & $1.93^{\mathrm{ab}}$ & $1.86^{\mathrm{ab}}$ & $1.78^{a b}$ & $1.60^{\mathrm{b}}$ & $1.91^{\mathrm{ab}}$ & $1.80^{\mathrm{ab}}$ & 0.028 \\
\hline Viscerosomatic index (VSI) ${ }^{6}$ & & $4.49^{a}$ & $3.90^{\mathrm{ab}}$ & $3.95^{\mathrm{ab}}$ & $3.82^{a b}$ & $3.75^{b}$ & $3.94^{\mathrm{ab}}$ & $4.26^{\mathrm{ab}}$ & 0.049 \\
\hline Whole body composition & Initially & & & & & & & & \\
\hline Moisture & $65.7^{\mathrm{a}}$ & $64.7^{\mathrm{b}}$ & $64.0^{b}$ & $64.2^{b}$ & $63.1^{\mathrm{b}}$ & $63.2^{\mathrm{b}}$ & $64.2^{b}$ & $64.2^{b}$ & 0.02 \\
\hline Protein $(\% \mathrm{DM})$ & 50.1 & 49.0 & 47.8 & 47.8 & 46.9 & 46.5 & 48.6 & 48.0 & 0.04 \\
\hline Fat $(\% \mathrm{DM})$ & $34.7^{\mathrm{b}}$ & $37.7^{\circ}$ & $37.8^{b}$ & $38.0^{\mathrm{b}}$ & $38.2^{b}$ & $38.0^{\mathrm{b}}$ & $37.7^{\mathrm{b}}$ & $38.0^{\circ}$ & 0.01 \\
\hline Ash (\% DM) & 13.7 & 13.3 & 13.3 & 12.8 & 13.3 & 13.3 & 13.7 & 13.1 & 0.29 \\
\hline
\end{tabular}

Values are means $(n=3)$. Values in the same row with different superscript letters are significantly different $(P<0.05)$.

SGR: $100 \times$ (In final body weight - In initial body weight)/60 days.

${ }^{2}$ FGR: dry feed intake/wet weight gain.

${ }^{3}$ Values are corrected by the $\%$ nutrient dilution.

${ }^{4}$ Protein retention: whole body protein gain/crude protein intake.

${ }^{5}$ HSI: $100 \times($ liver weight/body weight).

${ }^{6}$ VSI: $100 \times($ viscera weight/body weight). 


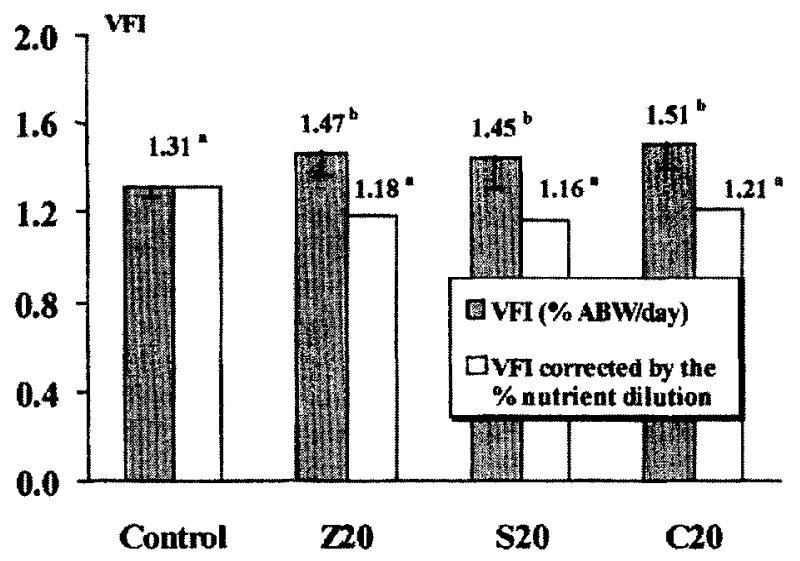

Figure 1. Voluntary feed intake of the various experimental diets as affected by their nutrient densily. ABW: Average body weight; values with different superscript letters are significantly different $(P<0.05)$.

The palatability properties of the various dietary bulk agents incorporated at $10 \%$ level (second feed consumption trial) are shown in figure 2. The VFI of fish fed the control diet $(1.29 \%)$ was significantly higher than the values obtained for all other experimental treatments $(1.19,1.17$ and $0.99 \%$ for $\mathrm{C} 10, \mathrm{Z} 10$ and $\mathrm{S} 10$ respectively)

\subsection{Feed transit time}

Bulk agents incorporation affected the feed transit time of the diets (figure 3). For all diets, faeces emission started approximately $5 \mathrm{~h}$ after fish were fed.

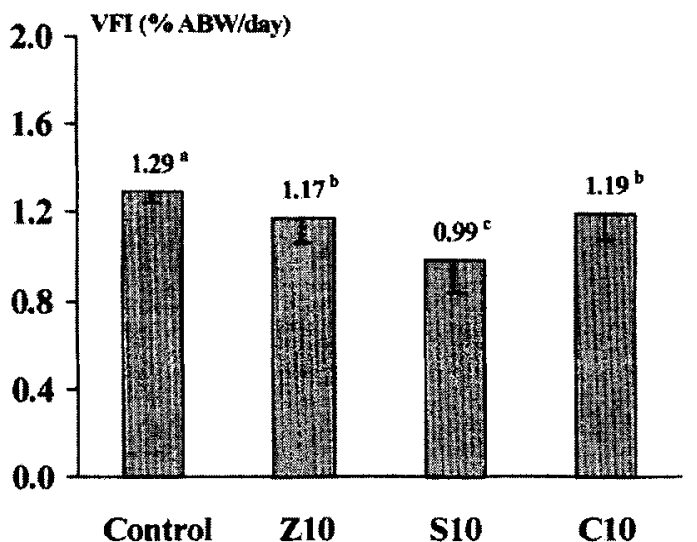

Figure 2. Voluntary feed intake of the various experimental diets as affected by the palatability properties of the bulk agents. $\Lambda \mathrm{BW}$ : Average body weight; values with different superscript letters are significantly different $(P<0.05)$.

However, the end of faeces egestion was sequential. In fish fed the control diet, the totality of faeces was expelled after $31 \mathrm{~h}$, whereas for fish fed with $20 \%$ of bulk-incorporated diets, faeces egestion continued over $35 \mathrm{~h}$. A significant increase in total faecal waste production was observed in fish fed diets with $20 \%$ of non-nutritive fillers. Total faeces egested by fish fed with the control diet corresponded to $3 \%$ of dry feed intake. In fish fed the $20 \%$ bulk-incorporated diets, the faeces egestion represented 6,10 and $13 \%$ for $Z 20$, S20 and C20 respectively.

Faeces egested (as \% of feed intake)

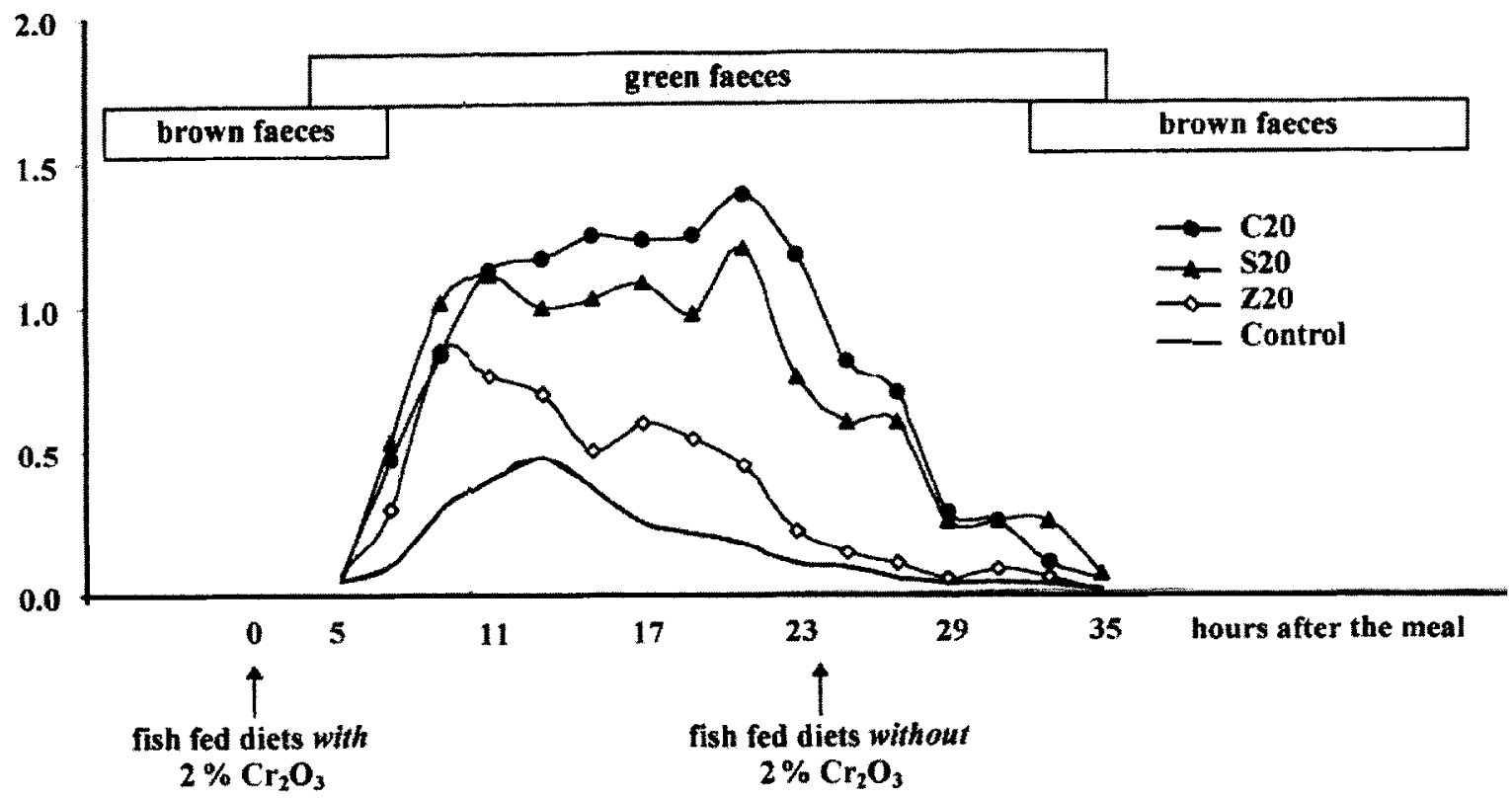

Figure 3. Hourly faecal egestion after a given meal as affected by bulk agents incorporation. 


\section{DISCUSSION}

The dietary incorporation of up to $20 \%$ of the various bulk agents did not significantly affect the apparent digestibility of proteins in seabass. In this same species, Spyridakis et al. [35] found that the use of $15 \%$ sodium alginate as a dietary binder negatively affected protein and lipid digestibility. Similarly, Storebakken [36] and Storebakken and Austreng [37] reported that increasing levels $(2.5,5$ and $10 \%)$ of alginate and guar gum in rainbow trout diets reduced protein and fat digestibility. Lanari et al. [19] tested the use of Cuban zeolites in rainbow trout diets and found that protein and dry matter digestibility was not influenced by zeolite incorporation at 2.5 and $5 \%$ levels.

Our findings indicate that the dietary use of silica, cellulose or a natural zeolite as bulk agents at 10 and $20 \%$ level had no adverse effect on seabass growth. The feed efficiency was negatively affected by the dietary use of bulk agents, but if the percent nutrient dilution of the diets is taken into account, the feed:gain ratio (FGR) values of fish fed the bulk-incorporated diets are similar to the FGR of fish fed the control diet. The growth rates observed in this study (ranging from 1.14 to $1.23 \%$ ) are in agreement with the earlier findings of Alliot et al. [1] and Métailler and Huelvan [21], working with the same species and with fish of similar size.

Cellulose has been commonly used as a non-nutrient filler agent in fish nutrition studies; however, some controversy seems to persist about its level of dietary incorporation. Alliot et al. [1] reported that a $15 \%$ level of cellulose incorporation did not influence seabass growth. For rainbow trout, no significant changes in growth performance were observed with up to a $30 \%$ level of cellulose incorporation [5]. On the other hand, Hilton et al. [14] and Poston [24] observed, for the same species, a growth depression with a level of cellulose incorporation above $8 \%$.

Silicates, more commonly known as bentonite, kaolin, zeolites and other clays, have been used in poultry and swine nutrition for many years. Some researchers have observed beneficial effects on growth, feed efficiency and nutrient utilization [22] while others have found negative or no growth response to these inert fillers $[29,33]$. In fish nutrition, their use is rare and these alumino-silicates have been tested mostly as trace minerals supplements or as ammonia adsorbers in aquaculture effluent waters [11, 27]. According to Lanari et al. [19], the addition of zeolites $(2.5$ and $5 \%)$ to rainbow trout diets improved weight gain and feed efficiency. Similarly, Smith [34] also reported that rainbow trout, fed with diets which had up to $10 \%$ incorporation of sodium bentonite, presented growth and feed efficiency improvement. The use at a 5 and $10 \%$ level of clinoptiolite (a natural zeolite) did not affect the growth of coho salmon [11]. However, Reinitz [26] found that the dietary addition of sodium bentonite, at 5, 10 and $15 \%$ levels, reduced weight gain in rainbow trout. Moreover, fish fed the diet with $15 \%$ sodium bentonite showed epithelial swelling of kidney tubules [26].

The addition of various inert fillers keeps the dietary protein/energy ratio constant but, by dilution, lowers the proportion of individual nutrients and energy. At 10 and $20 \%$ levels, the incorporation of bulk agents did not affect protein retention values. Shiau and Liang [31] reported a better utilization of dietary protein when they tested agar supplementation at two dietary protein levels in hybrid tilapia. They suggested that this effect could be related to a slower feed passage time through the gastrointestinal tract, that might enhance overall nutrient absorption. However, it is important to recall that in our study, the apparent digestibility of protein was not affected by the dietary use of inert fillers.

In terms of whole-body composition, results show that, compared to the initial group, all treatments groups had decreased moisture content and increased fat content. No differences were found within experimental treatments. Bulk incorporation tended to reduce hepatosomatic and viscerosomatic indexes, but the variability of values was not clearly attributable to any dietary changes.

Dietary bulk incorporation, at $20 \%$ level, significantly increased the voluntary feed intake (VFI) of seabass. However, if the percent dietary nutrient dilution is taken into account, corrected VFI values did not differ among experimental treatments. These results confirm the well-recognized idea that fish are able to adjust their voluntary feed intake to meet their energy requirements $[4,6]$. According to Bromley and Adkins [5], rainbow trout was able to compensate dietary nutrient dilution by $\alpha$-cellulose up to a $30 \%$ level. However, fish failed to compensate their feed intake for higher levels ( 40 and $50 \%$ ) of this indigestible filler.

In relation to the palatability properties of the different diets, the preliminary results obtained demonstrate that all the bulk agcnts (and particularly silica) negatively affected the voluntary feed intake. However, results from the growth trial (60 days) clearly indicate that there are no long term palatability problems, as fish fed bulk-incorporated diets increased their feed consumption. Besides the nutrient density and palatability of the diets, other factors such as environmental factors, physical properties of the feeds and feeding practices assume great importance in the regulation of voluntary feed intake [3, 16].

The main factors that influence feed transit time are temperature, fish size, feed intake, feed formulation and composition [12]. The majority of studies on this subject, report that the use of feeds containing high levels of indigestible fibres lead not only to a substantial increase in faecal egestion, but also to a decrease of feed transit time $[5,14,24]$. Our results show an increase in total faecal output of fish fed the diets with $20 \%$ bulk incorporation. Even without a precise measurement of the physical properties of faeces (such as 
firmness or settlement rate), the manipulation of faeces during collection showed that bulk agents incorporation increased faeces firmness. This increase of total faecal wastes is a major drawback in terms of environmental protection [17]. However, the aspects concerning the physical properties of faeces deserve further investigations, as an increase in faeces cohesion may enhance the efficiency of settlement and removal by suspended solids systems, particularly in recirculatedwater rearing conditions. Furthermore, due to their high cation exchange capacity for $\mathrm{NH}_{4}^{+}$, zeolites aroused some interest in fish nutrition as ammonia adsorbers in effluent waters. However, studies by Edsall and Smith [11] and Lanari et al. [19] failed to demonstrate any significant effect of dietary zeolites on reducing effluent water ammonia concentration.

In comparison to the control diet, the incorporation of the indigestible fillers, at $20 \%$ level, modified the faecal egestion profile and increased feed transit time. In rainbow trout, the incorporation of a high-viscosity guar gum (up to a $8 \%$ level) was found to delay stomach emptying time [36]. However, in the same study, this effect was not observed with a medium-high viscosity sodium alginate. On the other hand, Hilton et al. [14] reported that 10 and $20 \%$ levels of $\alpha$-cellulose incorporation in rainbow trout diets, increased gastric evacuation rate. Similar findings have also been reported for tilapia fed high-carboxymethylcellulose diets [31] and for trout fed kaolin diluted diets [13].
These contradictory results on the effects of non-nutritive fillers incorporation on feed evacuation time in fish, are in some cases related to the different physicochemical properties of the various bulk agents tested [30]. Their properties, such as ion-binding or waterholding capacity, have a strong influencc on solubility, gelling and viscosity of food during its passage through the gastrointestinal tract [37]. Furthermore, stomach $\mathrm{pH}$ seems to influence these properties and consequently, species differences in response to dietary inert fillers should also be taken into account.

\section{CONCLUSION}

This study is a preliminary approach to the use of high dietary levels of non-nutritive fillers in diets for European seabass. The dietary use of silica, cellulose or a natural zeolite as bulk agents, at 10 and $20 \%$ level, had no adverse effect on protein digestibility, growth and feed utilization. Voluntary feed intake was affected by the inert fillers incorporation, but within the tested levels, fish were able to compensate the nutrient dilution. The incorporation at $20 \%$ level of the various bulk agents increased total faecal egestion and delayed feed transit time. To fully evaluate the use of these dietary bulk agents, aspects concerning the settlement and removal of suspended solids in aquaculture effluent waters deserve further investigations.

\section{Acknowledgements}

These results were presented during the III International Symposium on Nutritional Strategies and Management of Aquaculture Waste, Vila Real, Portugal, 2-4 October 1997. Authors wish to thank Dr S.J. Kaushik and Dr J. Guillaume for critical assessment of the work. J.D. was supported by a grant (BD 5615/95) from Junta Nacional de Investigação Cicntífica c Tecnológica (JNICT), Portugal.

\section{REFERENCES}

[1] Alliot E., Pastoureaud A., Nedelec J., Étude de l'apport calorique et du rapport calorico-azoté dans l'aliment du bar, Dicentrarchus labrax. Influence sur la croissance et la composition corporelle, in: Halver J.E., Tiews K. (Eds.), Proc. World Symp. on Finfish Nutrition and Fishfeed Technology, vol. I, Hamburg, Germany, 1979, pp. 241-251.

[2] Bolin D.W., King R.P., Klosterman E.W., A simplified method for the determination of chromic oxide $\left(\mathrm{Cr}_{2} \mathrm{O}_{3}\right)$ when used as an index substance, Science 116 (1952) 634-635.

[3] Boujard T., Leatherland J.F., Circadian rhythms and feeding time in fishes, Environ. Biol. Fishes 35 (1992) 109-131.

[4] Boujard T., Médale F,, Regulation of voluntary feed intake in juvenile rainbow trout fed by hand or by self- feeders with diets containing two different protein/ energy ratios, Aquat. Living Resour. 7 (1994) 211-215.

[5] Bromley G., Adkins T.C., The influence of cellulose filler on feeding, growth and utilization of energy in rainbow trout, Salmo gairdneri Richardson, J. Fish Biol. 24 (1984) 235-244.

[6] Cho C.Y., Feeding systems for rainbow trout and other salmonids with reference to current estimates of energy and protein requirements, Aquaculture 100 (1992) 107123.

[7] Cho C.Y., Digestibility of fecdstuffs as a major factor in aquaculture waste management, in: Kaushik S.J., Luquet $\mathrm{P}$. (Eds.), Fish nutrition in practice, Inra éditions Les Colloques n 61, France, 1993, pp. 365-374.

[8] Cho C.Y., Hynes J.D., Wood K.R., Yoshida H.K., Quantitation of fish culture waste by biological (nutritional) and chemical (limnological) methods: the development of high nutrient dense (HND) diets, in: Cowey C.B., Cho C.Y. (Eds.), Nutritional strategies and aquaculture

Aquat. Living Resour. 11 (4) (1998) 
waste, Proc. First Int. Symp. Nutritional Strategies and Management of Aquaculture Waste, Univ. Guelph, Guelph, Ontario, Canada, 1991, pp. 37-50.

[9] Choubert G., De la Noüe J., Luquet P., Digestibility in fish: improved device for the automatic collection of faeces, Aquaculture 29 (1982) 185-189.

[10] Dioundick O.B., Stom D.I., Effects of dietary-cellulose levels on the juvenile tilapia, Oreochromis mossambicus (Peters), Aquaculture 91 (1990) 311-315.

[11] Edsall D.A., Smith C.E., Effects of dietary clinoptilolite on levels of effluent ammonia from hatchery coho salmon, Progress. Fish Cult. 51 (1989) 98-100.

[12] Fänge R., Grove D.J., Digestion, in: Hoar W.S., Randall D.J., Brett J.R. (Eds.), Fish Physiology, vol. VIII, Academic Press, New York, 1979, pp. 161-260.

[13] Grove D.J., Loizides L.G., Nott J., Satiation amount, frequency of feeding and gastric emptying rate in Salmo gairdneri, J. Fish Biol. 12 (1978) 507-516.

[14] Hilton J.W., Atkinson J.L., Slinger S.J., Effect of increased dietary fiber on the growth of rainbow trout (Salmo gairdneri), Can. J. Fish. Aquat. Sci. 40 (1983) 81-85.

[15] Johnson I.T., Fiber sources for the food industry, Proc. Nutr. Soc. 49 (1990) 31-38.

[16] Kaushik S.J., Environmental effects on feed utilisation, Fish Physiol. Biochem. 2 (1986) 131-140.

[17] Kaushik S.J., Nutritional strategies for the reduction of aquaculture wastes, Proc. Fisheries and Ocean Industrial Development, Pusan, Korea, 1994, pp. 115-132.

[18] Kishimoto Y., Wakabayashi S., Takeda H., Hypocholesterolemic effect of dietary fiber: relation to intestinal fermentation and bile acid excretion, J. Nutr. Sci. Vitaminol. 41 (1995) 151-161.

[19] Lanari D., D'Agaro E., Turri C., Use of Cuban zeolites in trout diets, Riv. Ital. Acquacolt. 31 (1996) 23-33.

[20] Maynard L.A., Loosli J.K., Animal nutrition, 6th ed., McGraw-Hill, New York, 1969, 613 p.

[21] Métailler R., Huelvan C., Utilisation de levures dans l'alimentation du juvénile de bar (Dicentrarchus labrax), in: Kaushik S.J., Luquet P. (Eds.), Fish nutrition in practice, Inra éditions Les Colloques $n^{\circ} 61$, France, 1993, pp. 945-948.

[22] Mumpton F.A., Fishman P.H., The application of natural zeolites in animal science and aquaculture, J. Anim. Sci. 45 (1977) 1188-1203.

[23] NRC (National Research Council), Nutrient requirements of fish, National Academy Press, Washington, DC, USA, 1993, $114 \mathrm{p}$.
[24] Poston H.A., Response of lake trout and rainbow trout to dietary cellulose, Fish Wildl. Tech. Rep., US Fish Wildl. Serv, 5, 1986, $6 \mathrm{p}$.

[25] Reddy B.S., Nutritional factors and colon cancer, Crit. Rev. Food Sci. Nutr. 35 (1995) 175-190.

[26] Reinitz G., The effect of nutrient dilution with sodium bentonite in practical diets for rainbow trout, Progress. Fish Cult. 46 (1984) 249-253.

[27] Rumsey G.L., Cement kiln dust as an additive in the diets of rainbow trout, Progress. Fish Cult. 43 (1981) 88-90.

[28] SAS, Statistical guide for personal computers, SAS Inst. Inc., North Carolina, USA, 1987, 1028 p.

[29] Sellers R.S., Harris Jr G.C., Waldroup P.W., The effects of various dietary clays and fillers on the performance of broiler and laying hens, Poultry Sci. 59 (1980) 19011906.

[30] Shiau S.Y., Role of fiber in fish feed, in: Shiau S.Y. (Ed.), Progress in fish nutrition, Mar. Food Sci. Ser. 9 (1989) 93-119.

[31] Shiau S.Y., Liang H.S., Nutrient digestibility and growth of hybrid tilapia, Oreochromis niloticus $\times$ $O$. aureus, as influenced by agar supplementation at two dietary protein levels, Aquaculture 127 (1994) 41-48.

[32] Shiau S.Y., Yu H.L., Hwa S., Chen S.Y., Hsu S.I., The influence of carboxymethylcellulose on growth, digestion, gastric emptying time and body composition of tilapia, Aquaculture 70 (1988) 345-354.

[33] Shurson G.C., Ku P.K., Miller E.R., Yokoyama M.T., Effects of zeolite a or clinoptilolite in diets of growing swine, J. Anim. Sci. 59 (1984) 1536-1545.

[34] Smith R.R., Nutritional bioenergetics in fish, in: Fish feed technology, UNDP, FAO, Rome, 1980, pp. 21-27.

[35] Spyridakis P., Métailler R., Gabaudan J., Studies on nutrient digestibility in European seabass (Dicentrurchus labrax), 2. Effect of sodium alginate on protein and lipid digestibility, Aquaculture 77 (1989) 71-73.

[36] Storebakken T., Binders in fish feeds. I. Effect of alginate and guar gum on growth, digestibility, feed intake and passage through the gastrointestinal tract of rainbow trout, Aquaculture 47 (1985) 11-26.

[37] Storebakken T., Austreng E., Binders in fish feeds. II. Effect of different alginates on the digestibility of macronutrients in rainbow trout, Aquaculture 60 (1987) 121-131.

[38] Zar J.H., Biostatistical analysis, 3rd ed., Prentice Hall, New Jersey, 1996, 662 p. 